Tersedia online di: http://ejournal-balitbang.kkp.go.id/index.php/bawal
e-mail:bawal.puslitbangkan@gmail.com
BAWAL wIDYA RISET PERIKANAN TANGKAP
Volume 9 Nomor 3 Desember 2017
e-ISSN: 2502-6410
NAWALr Akreditasi: 620/AU2/P2MI-LIPI/03/2015

\title{
PARAMETER POPULASI HIU KEJEN (Carcharhinus falciformis) DI PERAIRAN SELATAN NUSA TENGGARA BARAT
}

\section{POPULATION PARAMETERS OF SILKY SHARK (Carcharhinus falciformis) IN THE SOUTH OFF WEST NUSA TENGGARA WATERS}

\author{
Umi Chodrijah*1, Irwan Jatmiko $^{2}$, dan Agus Arifin Sentosa ${ }^{3}$ \\ ${ }^{1}$ Balai Riset Perikanan Laut, Cibinong, Bogor, Jl. Raya Bogor KM. 47 Nanggewer Mekar, Cibinong, Bogor \\ ${ }^{2}$ Loka Riset Perikanan Tuna, Jl. Mertasari No. 140 Br Suwung Kangin, Sidakarya, Denpasar Bali, 80224 \\ ${ }^{3}$ Balai Riset Pemulihan Sumber Daya Ikan, Jalan Cilalawi No. 01 Jatiluhur, Purwakarta, Jawa Barat, Indonesia-41152, \\ Teregistrasi I tanggal: 21 Agustus 2017; Diterima setelah perbaikan tanggal: 28 Desember 2017; \\ Disetujui terbit tanggal: 02 Januari 2018
}

\begin{abstract}
ABSTRAK
Hiu kejen atau silky shark (Carcharhinus falciformis) merupakan salah satu spesies hiu dari famili Carcharhinidae yang banyak tertangkap di Samudera Hindia Selatan Jawa. Berdasarkan keputusan sidang CoP17 di Johannesburg species ini masuk dalam daftar merah Apendik II CITES, sejak saat itu pengelolaan hiu kejen menjadi perhatian khusus pada perikanan tangkap. Tujuan penelitian ini adalah untuk mendapatkan informasi parameter populasi ikan hiu kejen di perairan Samudera Hindia bagian Selatan Nusa Tenggara. Penelitian dilakukan di Tempat Pendaratan Ikan Tanjungluar, Lombok Timur tahun 2016. Pengukuran contoh hiu meliputi panjang total tubuh, nisbah kelamin serta panjang klasper. Hasil penelitian terhadap 3002 ekor ikan contoh menunjukkan bahwa kisaran panjang total hiu kejen (Carcharhinus falciformis) antara 65-300 cm (betina) dan 74-315 cm (jantan). Rerata ukuran panjang total adalah $187,66 \mathrm{~cm}$ (betina) dan $195 \mathrm{~cm}$ (jantan). Parameter pertumbuhan menurut Von Bertalanffy, meliputi laju pertumbuhan $(\mathrm{K})$, panjang asimptotik $\left(\mathrm{L}_{\infty}\right)$ dan umur ikan pada saat panjang ke-0 $\left(\mathrm{t}_{0}\right)$, masing-masing sebesar 0,42/tahun; 331,28 cmTL dan -0,20/ tahun. Persamaan kurva pertumbuhan von Bertalanffy untuk hiu kejen yaitu $\mathrm{L}_{\mathrm{t}}=331,28\left[1-\mathrm{e}^{-0.42(\mathrm{t}+0.20)}\right]$. Parameter mortalitas hiu kejen meliputi laju kematian total (Z), laju kematian alamiah (M) dan laju kematian karena penangkapan (F) masingmasing sebesar 2,79/tahun; 0,49/tahun dan 2,30/tahun. Laju eksploitasi (E) hiu kejen sebesar 0,82 menandakan eksploitasi terhadap spesies ini cenderung sudah tinggi.
\end{abstract}

Kata Kunci: Carcharhinus falciformis; parameter populasi; Nusa Tenggara Barat

\section{ABSTRACT}

Silky shark (Carcharhinus falciformis) is one of the family Carcharhinidae that commonly caught in the Indian Ocean South of Java. The purpose of this study was to obtain information on the populations parameters of silky shark caught in the waters of Indian Ocean Southern part of Nusa Tenggara. The study was conducted at fish landing sites in Tanjungluar, East Lombok from January to December 2016. The method used in this research was survey method. Observations included total body length, sex ratio and clasper length measured with direct measurements and visual observations in the field. From a total 3002 fish samples showed that the total length range for silky shark (Carcharhinus falciformis) caught in the waters of the Indian Ocean landed in Tanjungluar were between 65-300 cm TL (female) and 74-315 cmTL (male), with the average length of 187, 66 cmTL (female) and $195 \mathrm{~cm} T L$ (male). The estimated Von Bertalanffy growth parameters of length infinity $\left(L_{\infty}\right)$, growth rate $(K)$ and theoretical age of fish at zero length $\left(t_{0}\right)$ were $331.28 \mathrm{cmTL}, 0.42 /$ year and -0.20 years, respectively. The Von Bertalanffy growth equation for silky shark was $L t=331.28\left[1-e^{-0.42(t+0.20)}\right]$. The calculated Parameters for silky shark mortality including total mortality rate $(Z)$, the natural mortality rate $(M)$ and the fishing mortality rate $(F)$ were 2.79 / year, 0:49/year and 2.30 / year, respectively. The exploitation rate $(E)$ of silky shark of 0.82 indicates the exploitation of this species has already high.

Keywords: Silky shark; population parameters; West Nusa Tenggara 


\section{PENDAHULUAN}

Hiu kejen (Carcharhinus falciformis) merupakan anggota dari suku Carcharhinidae, memiliki kelimpahan tinggi serta tersebar secara berkelompok di perairan pantai tropis (Compagno, 1984). Hiu kejen atau lanjaman merupakan sebutan dari jenis hiu C. falciformis (silky shark) yang umum dikenal oleh nelayan di Jawa, sedangkan di Bali dikenal dengan nama hiu mungsing dan nelayan di Lombok-Nusa Tenggara Barat mengenal dengan sebutan hiu lonjor atau kejen (White et al., 2006).

Secara umum, morfologi hiu kejen (C. falciformis) dicirikan oleh pangkal sirip punggung pertama di belakang ujung belakang sirip dada, sisi bagian dalam sirip punggung kedua sangat panjang antara 1,6 -3,0 kali tinggi siripnya, terdapat gurat diantara sirip punggung, moncong agak panjang, bulat menyempit (tampak dari arah bawah), gigi atas kecil dengan lekukan di satu sisinya, gigi bawah kecil, ramping dan tegak (White et al., 2006).

Ketersediaan data biologi hiu dan kelompok ikan bertulang rawan pada umumnya masih kurang memadai bila dibanding dengan data biologi dari jenis ikan bertulang keras (teleostei). Karakteristik biologi ikan hiu adalah mempunyai laju pertumbuhan lamban dan kematangan kelamin yang lambat; siklus perkembangbiakan yang lama; fekunditas rendah; dan rentang hidup yang panjang (FAO, 2000; Castro et al., 1999; Compagno, 1984; dan Last \& Stevens, 1994). Selain itu, banyak spesies hiu bernilai ekonomi penting mempunyai daerah asuhan (nursery area) di perairan pantai yang dangkal. Faktor tersebut mengakibatkan sumber daya ikan hiu sangat rentan terhadap tekanan penangkapan yang berlebihan.

Tempat Pendaratan Ikan Tanjungluar merupakan salah satu basis pendaratan utama hasil tangkapan hiu di wilayah Nusa Tenggara Barat. Ikan hiu yang tertangkap merupakan hasil tangkapan utama di perairan Samudera Hindia, terutama kelompok ikan hiu pelagis dan oseanik, seperti sebagian besar suku Carcharhinidae (Whaler sharks), Alopiidae (Thresher sharks), dan Sphyrnidae (Hammer sharks).

Tulisan ini bertujuan untuk mengetahui parameter populasi hiu kejen (Carcharhinus falciformis) dengan studi kasus di Tempat Pendaratan Ikan Tanjungluar, Nusa Tenggara Barat yang merupakan salah satu pendaratan ikan hiu di Indonesia. Informasi ini sangat diperlukan sebagai bahan dasar pengelolaan ikan hiu kejen sehingga dapat dimanfaatkan secara berkelanjutan.

\section{BAHANDANMETODE}

Penelitian ini dilakukan di Tempat Pendaratan Ikan Tanjungluar, Nusa Tenggara Barat (Gambar 1) pada bulan Januari sampai dengan Desember 2016. Identifikasi jenis hiu dilakukan dengan menggunakan beberapa referensi yaitu Last \& Stevens (1994), Tarp \& Kailola (1982) dan White et al. (2006).

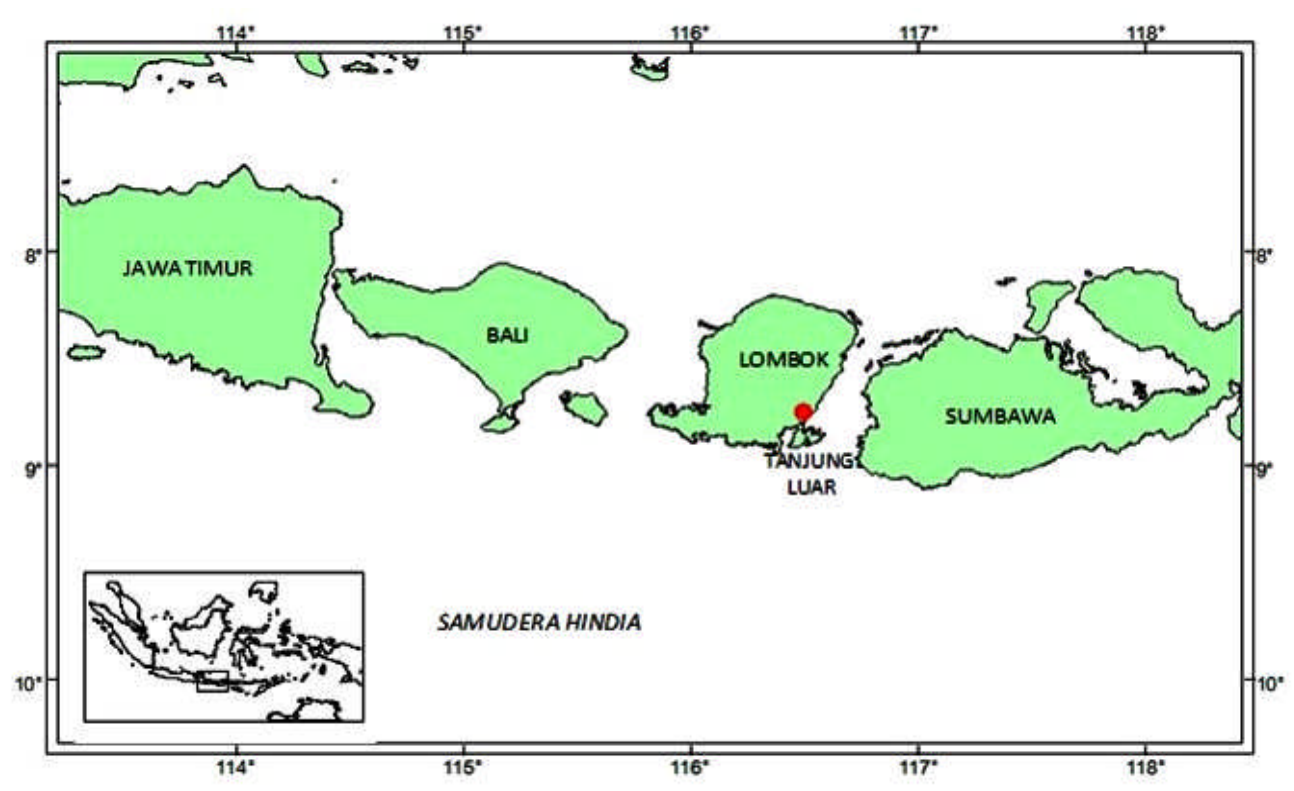

Gambar 1. Lokasi penelitian di Tanjungluar, Nusa Tenggara Barat.

Figure 1. Research site in Tanjungluar, West Nusa Tenggara.

Karakter biologi individu yang diukur antara lain panjang total $(\mathrm{cm})$ dan jenis kelamin. Penentuan jenis kelamin dilakukan berdasarkan ciri sepasang klasper (untuk hiu jantan), yaitu modifikasi dari kedua sirip perut hiu jantan yang digunakan sebagai alat kopulasi. Gambar ikan hiu kejen (Carcharhinus falciformis) yang menjadi obyek penelitian disajikan pada Gambar 2. 


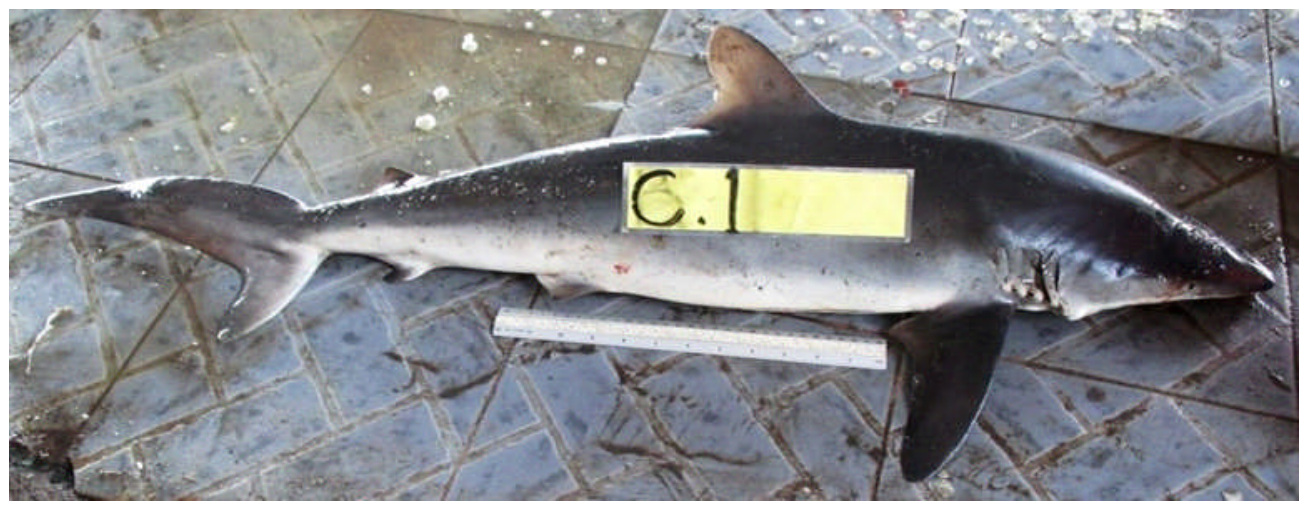

Gambar 2. Hiu kejen (Carcharhinus falciformis).

Figure 2. Silky shark (Carcharhinus falciformis).

Data frekuensi panjang merupakan salah satu informasi yang dapat digunakan untuk menduga parameter pertumbuhan dari suatu spesies ikan (Sparre \& Venema, 1992). Sedangkan jenis kelamin untuk menentukan nisbah kelamin dalam suatu populasi jenis ikan. Perhitungan nisbah kelamin didasarkan pada persamaan berikut :

$\mathrm{NK}=\mathrm{Nbi} / \mathrm{Nji}$

dimana:

$\mathrm{NK}=$ nisbah kelamin

$\mathrm{Nbi}=$ jumlah ikan betina pada kelompok ukuran ke-i

$\mathrm{Nji}=$ jumlah ikan jantan pada kelompok ukuran ke $\mathrm{i}$

Keseimbangan nisbah kelamin dilakukan dengan uji Chi-kuadrat (Steel \& Torrie, 1993);

$X^{2}=\sum_{i=1}^{k} \frac{(f o-f n)^{2}}{f n}$

dimana;

$\mathrm{X}^{2}=$ Chi Square

Fo $=$ frekuensi yang diobservasi

$\mathrm{Fn}=$ frekuensi yang diharapkan

Pendugaan parameter pertumbuhan dari Von Bertalanffy yaitu panjang total asimtotik $(\mathrm{L} \infty)$ dan koefisien pertumbuhan $(\mathrm{K})$ dihitung melalui pendekatan pergeseran bulanan modus (modal progression) ukuran ikan. Setiap modus diturunkan dengan metoda Batacharya (1967) dalam Sparre \& Venema (1999) mewakili kelompok umur ukuran yang tertangkap. Estimasi pertumbuhan dihitung dengan menggunakan persamaan linier seperti dikemukakan oleh Gulland \& Holt (1959) dalam Sparre \& Venema (1999):

$\frac{\Delta \mathrm{L}}{\Delta \mathrm{t}}=\mathrm{a}+\mathrm{b} * \mathrm{~L}(\mathrm{t})$

Hubungan linier diturunkan dari persamaan Von Bertalanffy sebagai berikut:
$\frac{\Delta \mathrm{L}}{\Delta \mathrm{t}}=\mathrm{K} *(\mathrm{~L} \infty-\mathrm{Lt})$

dimana $\mathrm{K}=-\mathrm{b}$ dan $\mathrm{L} \infty=-\mathrm{a} / \mathrm{b}$

Estimasi pertumbuhan dihitung melalui rata laju pergeseran modus $\bar{L}$ melalui persamaan:

$$
\bar{L}=\frac{L(t+\Delta t)+L(t)}{2}
$$

Pendugaan nilai t (umur pada saat 0 tahun berdasarkan persamaan Pauly (1984) yaitu;

$\log \left(-t_{0}\right)=0,3922-0,2752 \log \left(\mathrm{L}_{\infty}\right)-1.038 \log (\mathrm{K})$

Laju mortalitas alami (M) diduga dengan mengaplikasikan model empiris dari Pauly (1980) yaitu :

$\log (\mathrm{M})=-0,0066-0,279 * \log \left(\mathrm{L}_{\infty}\right)+0,6543 * \log$ $(\mathrm{K})+0,4634 * \log (\mathrm{T})$

dimana :

$\mathrm{L}_{\infty}=$ panjang asimtotik (cmTL)

$\mathrm{K}=$ kecepatan pertumbuhan

$\mathrm{T}=$ rataan suhu lingkungan perairan $=24^{\circ} \mathrm{C}$ (Compagno, 1984).

Koefisien mortalitas total (Z) diperoleh dari kurva hasil tangkapan berdasarkan panjang (length converted catch curve) (Pauly, 1983). Analisis parameter populasi dibantu dengan menggunakan paket program FISAT (Gayanilo et al., 2005). Koefisien mortalitas penangkapan $(\mathrm{F})$ dihitung dari persamaan :

$\mathrm{F}=(\mathrm{Z}-\mathrm{M})$

Laju eksploitasi (E) dihitung menggunakan persamaan:

$\mathrm{E}=\mathrm{F} / \mathrm{Z}$ 


\section{HASIL DAN BAHASAN \\ Hasil}

\section{Struktur Ukuran Panjang}

Pengukuran terhadap 3002 ekor ikan hiu kejen pada rentang waktu Januari - Desember 2016 diperoleh kisaran panjang total antara $65-300 \mathrm{~cm}$ (betina) dan 74-315 cm (jantan); rerata ukuran panjang 187,66 cm (betina) dan 195 cm (jantan) (Gambar 3). Hasil observasi panjang total ikan hiu kejen setiap bulannya disajikan pada Lampian 1 .

Berdasarkan hasil penelitian terhadap 3002 ekor hiu kejen (C. falciformis) pada tahun 2016 diperoleh jenis jantan 1255 ekor dan betina 1747 ekor dengan perbandingan antara betina dan jantan 1:0,72. Berdasarkan uji $\mathrm{X}^{2}$ diperoleh perbandingan jantan dan betina berbeda nyata. Sedangkan nisbah kelamin bulanan ikan hiu kejen disajikan pada Gambar 4.

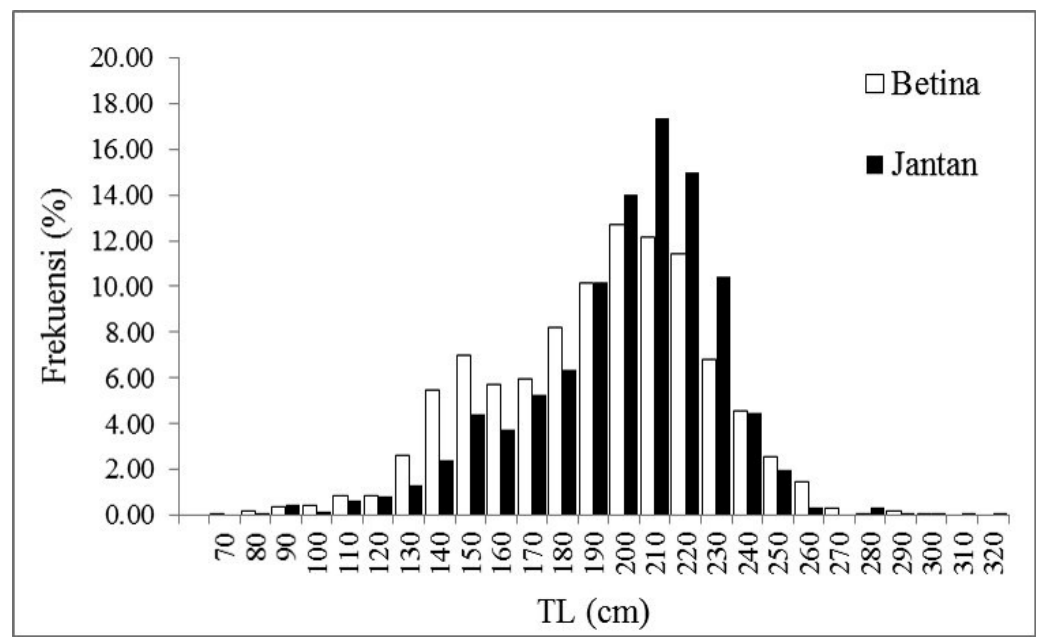

Gambar 3. Distribusi frekuensi panjang total ikan hiu kejen betina dan jantan.

Figure 3. Total length frequency distribution of Silky shark (female and male).

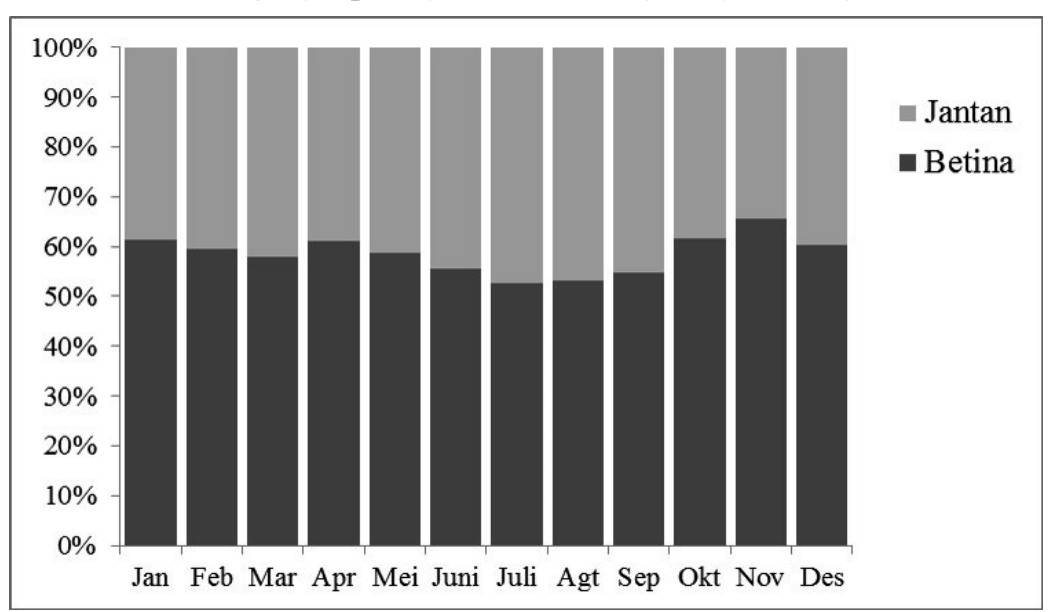

Gambar 4. Nisbah kelamin ikan hiu kejen dari perairan Selatan Nusa Tenggara, tahun 2016.

Figure 4. Sex ratio of Silky shark caught from Southern Nusa Tenggara waters, 2016.

Analisis dengan pendekatan pergeseran modus ukuran ikan yang tertangkap kemudian digrafikan melalui regresi antara perubahan ukuran panjang per satuan waktu $(d L /$ $d t$ ) dan rerata modus $\bar{L}$ (ukuran panjang ikan (Sparre \& Venema, 1999). Analisis grafikal tersebut menghasilkan estimasi nilai panjang asimtotik $(\mathrm{L} \infty)$ sebesar $331,28 \mathrm{~cm}$ dan laju pertumbuhan $(K)=0,42$ per tahun.

Estimasi parameter pertumbuhan Von Bertalanffy untuk spesies ini adalah $L \infty=331,28 \mathrm{~cm}, K=0,42 /$ th dan $t_{0}=$ 0,20 tahun mengikuti persamaan yaitu :

$$
\mathrm{L}_{\mathrm{t}}=331,28\left(1-\mathrm{e}^{[0,42(\mathrm{t}+0,20)]}\right)
$$

Mortalitas total (Z) yang diturunkan dari kurva tangkapan yang dilinierkan memberikan hasil sebesar 2,79/ th, sedangkan mortalitas alami $(M)$ pada suhu $24^{\circ} \mathrm{C}$ adalah 0,49/th (Gambar 5). Dengan menggunakan persamaan empiris diperoleh perkiraan laju kematian akibat penangkapan sebesar 2,30/th. Perkiraan tingkat eksploitasi (E) hiu kejen di perairan Selatan Nusa Tenggara yang diturunkan berdasarkan persamaan memberikan perkiraan nilai $E$ sebesar 0,82 . 


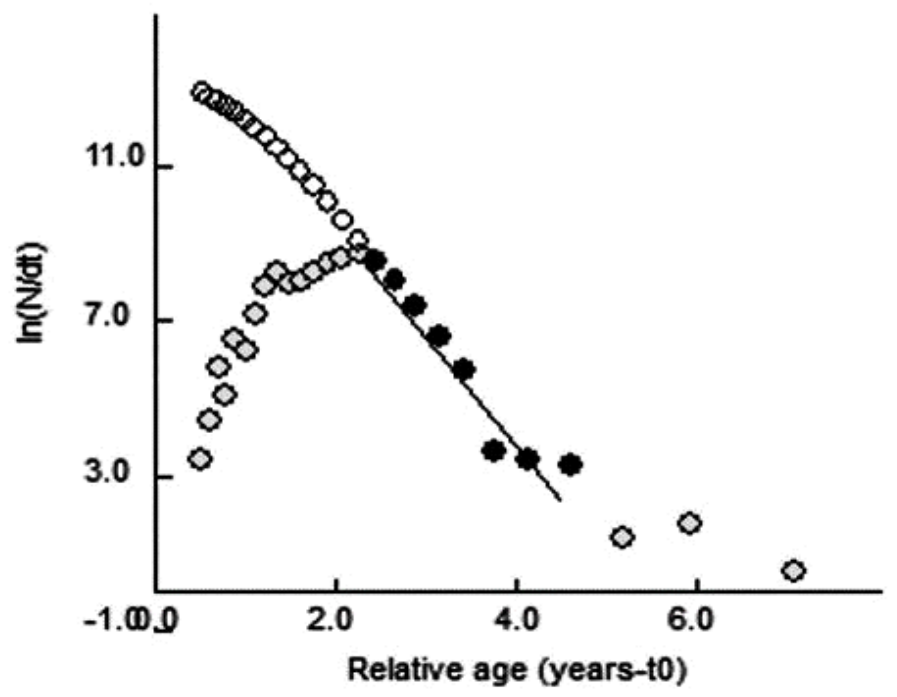

Gambar 5. Estimasi nilai Z sebagai slope kurva konversi hasil tangkapan ikan hiu kejen.

Figure 5. The estimated value of total mortality (Z) as a slope of length converted catch curve of Silky shark.

\section{Bahasan}

Hiu kejen (Carcharhinus falciformis) merupakan salah satu jenis ikan hiu yang umum tertangkap di perairan Selatan Nusa Tenggara. Jenis ini merupakan hasil tangkapan sampingan pada perikanan rawai tuna di Samudera Hindia, akan tetapi di Tanjungluar merupakan target tangkapan utama (Blaber et al., 2009; White et al., 2012; Fahmi \& Dharmadi, 2013). Hiu kejen yang tertangkap mempunyai kisaran panjang total antara $65-300 \mathrm{~cm}$ untuk betina dan $74-315 \mathrm{~cm}$ untuk jantan. Dari nilai kisaran panjang tersebut, diperoleh hanya $17 \%$ betina dan $35 \%$ jantan yang tertangkap di atas panjang pertama kali matang gonad (Branstetter, 1987). Dharmadi et al., (2007) menyatakan bahwa modus ukuran ikan hiu lanjaman $(C$. falciformis) adalah $190 \mathrm{~cm}$ dan termasuk dalam kelompok ikan hiu yang berumur muda. Kohler et al., (1995) menyatakan bahwa ukuran hiu Carcharhinus falciformis yang tertangkap di Atlantik Utara berkisar antara 90-258 cm. Menurut Chodrijah \& Faizah (2015) sebagian besar $(81,5 \%)$ hiu kejen betina yang tertangkap di perairan yang sama dalam kondisi relatif masih muda. Selanjutnya Bartron (2006) mengelompokkan hiu kejen menjadi dua kelompok umur yaitu kelompok hiu muda yang memiliki panjang total 186,4 cm berumur 9 tahun, dan kelompok hiu dewasa (tua) yang memiliki panjang total 242,9 $\mathrm{cm}$ dan berumur 19 tahun.

Berdasarkan hasil penelitian, nisbah kelamin hiu kejen (C. falciformis) dalam kondisi tidak seimbang $(\mathrm{P}<0,05)$ karena didominasi oleh ikan betina dengan perbandingan antara betina dan jantan 1:0,72. Hasil penelitian ini seiring dengan Chodrijah \& Faizah (2015) menyatakan bahwa perbandingan kelamin hiu Carcharhinus falciformis jantan dan betina dalam keadaan tidak seimbang dengan jumlah betina lebih besar. Perbandingan tersebut kurang ideal untuk keberlangsungan proses reproduksi suatu spesies ikan di suatu perairan, dikarenakan peluang untuk memperoleh pasangan untuk reproduksi berkurang atau individu jantan bersaing dengan individu jantan yang lain untuk mendapatkan pasangan.

Menurut hasil penelitian, hasil tangkapan hiu kejen di perairan Nusa Tenggara Barat didominasi oleh ikan-ikan yang belum matang gonad. Kondisi demikian tidak mendukung bagi kelestarian spesies ini karena mayoritas ikan yang tertangkap adalah ikan muda dan belum memiliki kesempatan memijah sekali dalam siklus hidupnya (King, 2010).

Analisis dengan program FiSAT, menunjukkan ikan hiu kejen diperkirakan mampu tumbuh hingga mencapai panjang asimtotik $331,28 \mathrm{~cm}$ dengan laju pertumbuhan sebesar 0,42 per tahun. Nilai panjang asimtotik dari hasil penelitian ini lebih besar jika dibandingkan dengan hasil penelitian di wilayah perairan lainnya, kecuali di Perairan Taiwan ( $L_{\infty}=332 \mathrm{cmTL}$ ) (Joung et al., 2008). Meskipun demikian perbedaan panjang asimtotiknya tidak signifikan (kurang dari $1 \mathrm{~cm}$ ). Perbedaan karakteristik lingkungan perairan diduga menjadi faktor utama perbedaan panjang asimtotik ini. Beberapa penelitian lain terkait spesies yang sama di perairan yang berbeda diperlihatkan pada (Tabel 1). 
Tabel 1. Panjang asimtotik $\left(L_{\infty}\right)$ dan laju pertumbuhan $(K)$ ikan hiu kejen dari berbagai lokasi penelitian. Table 1. Asymptotic length $\left(L_{\infty}^{\infty}\right)$ and growth rate $(K)$ of Silky shark from several locations.

\begin{tabular}{|c|c|c|c|c|}
\hline Lokasi / Location & $\mathbf{L} \infty(\mathbf{c m})$ & $\begin{array}{l}\text { K (tahun / } \\
\text { year) }\end{array}$ & $\begin{array}{l}\text { to }(\text { tahun / } \\
\text { year) }\end{array}$ & Penulis /Author \\
\hline Gulf of Mexico, Mexico & 291,0 & 0,15 & $-2,2$ & Branstetter (1987) \\
\hline Perairan Taiwan & 332,0 & 0,08 & $-2,76$ & Joung et al. (2008) \\
\hline Baja California, Mexico & 240,0 & 0,14 & $-2,98$ & Sanchez et al. (2010) \\
\hline Samudera Pasifik & 216,4 & 0,148 & $-1,76$ & Oshitani et al. (2003) \\
\hline $\begin{array}{l}\text { Banyuwangi, Jawa Timur, } \\
\text { Indonesia } \\
\text { Nusa Tenggara Barat, Indonesia }\end{array}$ & $\begin{array}{l}370,05(\mathrm{~B}) \\
319,00(\mathrm{~J}) \\
331,28\end{array}$ & $\begin{array}{l}0,34(\mathrm{~B}) \\
0,20(\mathrm{~J}) \\
0,42\end{array}$ & $\begin{array}{l}-0,24(B) \\
-0,44(\mathrm{~J}) \\
-2,4\end{array}$ & $\begin{array}{l}\text { Damora \& Yuneni } \\
(2015) \\
\text { Penelitian ini (2017) }\end{array}$ \\
\hline
\end{tabular}

Selanjutnya menurut Pauly 1980 dalam Sparre \& Venema (1999), nilai K merupakan suatu parameter yang menentukan seberapa cepat ikan mencapai panjang asimtotiknya. Ikan dengan nilai $\mathrm{K}$ yang relatif rendah pada umumnya memiliki umur yang relatif panjang.

Kejadian yang hampir sama juga terjadi pada koefisien pertumbuhan, dimana nilainya $(K=0,42 /$ th $)$ lebih tinggi dibandingkan dengan yang terjadi di perairan lainnya seperti di Gulf of Mexico, Mexico (Branstetter, 1987), perairan Taiwan (Joung, et al., 2008), Baja California, Mexico (Sanchez, et al., 2010) dan di Samudera Pasifik (Oshitani, et al., 2003) (Tabel 1).

Untuk mengetahui perkiraan laju pemanfaatan, perhitungan laju kematian karena penangkapan $(F)$ bervariasi menurut keragaman upaya penangkapan (f) setiap tahunnya. Nilai F menunjukkan seberapa besar dan meningkatnya tekanan penangkapan (fishing pressure) terhadap stok ikan di suatu perairan (Suman \& Boer, 2005);

Jika nilai mortalitas alami dari ikan hiu kejen, $\mathrm{M}=0,49$ per tahun dan mortalitas penangkapan $\mathrm{F}=2,30$ per tahun maka diperoleh nilai tingkat eksploitasi $\mathrm{E}=0,82$. Tingkat eksploitasi hiu kejen (C. falciformis) di perairan Nusa Tenggara Barat ini lebih tinggi dari nilai rerata tingkat eksploitasi $(\mathrm{E}=0,5)$. Pauly et al., (1984) menyebutkan bahwa nilai laju eksploitasi yang rasional dan lestari di suatu perairan berada pada nilai $\mathrm{E}<0,5$ atau paling tinggi pada nilai $\mathrm{E}=0,5$.

Hal ini berarti tingkat eksploitasi ikan hiu kejen terindikasi dalam kondisi lebih tangkap (over fishing). Hiu kejen merupakan salah satu spesies yang memiliki kerentanan tinggi dalam hal eksploitasi. Bukan hanya tekanan dari aktivitas penangkapan, tetapi juga karena karakteristik biologinya yang membutuhkan waktu lama untuk mencapai matang gonad dan tingkat rekruitmennya sangat rendah (Hazin et al., 2007).

\section{KESIMPULAN}

Hiu kejen (Carcharhinus falciformis) yang tertangkap di perairan Selatan Nusa Tenggara berukuran antara 65$300 \mathrm{cmTL}$ (betina) dan antara 74-315 cmTL (jantan). Rerata ukuran panjang adalah 187,66 (betina) dan 195 (jantan). Parameter pertumbuhan Von Bertalanffy, meliputi laju pertumbuhan $(\mathrm{K})$, panjang asimptotik $\left(\mathrm{L}_{\infty}\right)$ dan umur ikan pada saat panjang ke- $0\left(\mathrm{t}_{0}\right)$, masing-masing sebesar $0,42 /$ tahun; 331,28 cm TL dan -0,24/ tahun. Persamaan kurva pertumbuhan Von Bertalanffy untuk hiu kejen sebagai $\mathrm{L}_{\mathrm{t}}=$ $331,28\left[1-\mathrm{e}^{-0.42(1+0.20)}\right]$. Parameter mortalitas untuk hiu kejen, meliputi laju kematian total (Z), laju kematian alamiah (M) dan laju kematian karena penangkapan (F), masing-masing sebesar 2,79/tahun, 0.49/tahun dan 2,30/tahun. Laju eksploitasi (E) hiu kejen sebesar 0,82/tahun menandakan eksploitasi terhadap spesies ini sudah tinggi.

\section{PERSANTUNAN}

Tulisan ini merupakan bagian dari kegiatan "Penelitian karakteristik biologi perikanan, habitat sumber daya ikan dan potensi produksi sumberdaya perikanan di WPP 573 (Samudera Hindia Selatan Jawa dan Nusa Tenggara)" pada Balai Penelitian Perikanan Laut Muara Baru, Jakarta Tahun Anggaran 2016. Penulis mengucapkan terima kasih kepada petugas enumerator di TPI. Tanjungluar yang telah membantu dalam pengumpulan data selama penelitian.

\section{DAFTAR PUSTAKA}

Bartron, C., W. T. White, Dharmadi \& C. Potter. (2006). Biology of the Silky Shark Carcharhinus falciformis (Carcharhinidae) in the Eastern Indian Ocean where it is commercially important.

Blaber, S.J.M., Dichmont, C.M., White, W., Blucworth, R., Sadiyah, L, Iskandar,B., Nurhakim, S., Pillans, R. Andamari, R., Dharmadi \& Fahmi. (2009). Elasmobranchs in southern Indonesian fisheries: The fisher- 
ies, the status of the stocks and management options. Reviews in Fish Biology and Fisheries, 19(3), 367-391.

Branstetter, S. (1987). Age, growth and reproductive biology of the silky shark, Carcharhinus falciformis, and the scalloped hammerhead, Sphyrna lewini, from the Northwestern Gulf of Mexico. Environmental Biology of Fishes. 19(3), 161-173.

Castro, J.L., C.M. Woodley \& L.L. Brudek. (1999). A preliminary evaluation of the status of shark species. FAO Fisheries. Tech. Pap. (380), 72 pp.

Chodrijah, U \& R. Faizah. (2015). Struktur Ukuran dan Nisbah kelamin ikan hiu kejen (Carcharhinus falciformis) di perairan Selatan Nusa Tenggara Barat. Prosiding Simposium Hiu dan Pari di Indonesia.p. 43-49.

Compagno, L. J. V. (1984). Sharks of the world. An annotated and illustrated catalogue of shark species known to /Date. Food and Agricultural Organization.pp.470472. (125) Vol.4. Pt.250-655.

Damora, A. \& R. R. Yuneni (2015). Estimasi pertumbuhan, mortalitas dan eksploitasi hiu kejen (Carcharhinus falciformis) dengan basis pendaratan di Banyuwangi, Jawa Timur. Prosiding Simposium Hiu dan Pari di Indonesia.p. 1-8.

Dharmadi, Fahmi \& Adrim, M. (2007). Distribusi frekuensi panjang, hubungan panjang tubuh, panjang klasper, dan nisbah kelamin hiu lanjaman (Carcharhinus falciformis). J. Lit. Perikan. Ind. 13(3), 243-254.

FAO. (2000). Fisheries Management: 1. Conservation and Management of Sharks. FAO Tech. Guidelines for Responsible Fisheries. Suppl. 1. FAO. Rome, 37 pp.

Fahmi \& Dharmadi. (2013). Tinjauan status perikanan hiu dan upaya konservasinya di Indonesia (p.179). Jakarta: Direktorat Konservasi Kawasan dan Jenis Ikan Direktorat Jenderal Kelautan, Pesisir dan Pulau-Pulau Kecil.

Gayanilo, F.C.Jr., Sparre, P \& Pauly, D. (2005). FAO-ICLARM Stock Assessment Tools II (FiSAT II). Revised version. User's guide. FAO Computerized Information Series (Fisheries). No. 8, Revised version. Rome, FAO, 168 p.

Hazin, F.H.V., P.G.V. Oliveira \& B.C.L. Macena. (2007). Aspects of the reproductive biology of the silky shark, Carcharhinus falciformis (Nardo, 1827), in the vicinity of archipelago of Saint Peter and Saint Paul, in the equatorial Atlantic Ocean. Col. Vol. Sci. Pap. ICCAT. 60(2), 648-651.
Joung, S.J., C.T. Chen, H.H. Lee \& K.M. Liu. (2008). Age, growth, and reproduction of silky sharks, Carcharhinus falciformis, in Northeastern Taiwan waters. Fisheries Research.90(1-3), 78-85.

King, M. (2010). Fisheries Biology, Assessment and Management, Second Edition (p. 381). Oxford, England: Blackwell Publising Ltd.

Kohler, N.E., Casey J.G \& Turner, PA. (1994). Lengthweight relationship for 13 soecies of sharks from the Western North Atlantic. Fishery Bulletin 93(2).

Last, P.R. \& J.D. Stevens. (1994). Sharks and rays of Australia. CSIRO. Australia, $513 \mathrm{pp}$.

Oshitani, S., H. Nakano \& S. Tanaka. (2003). Age and growth of the silky shark Carcharhinus falciformis from the Pacific Ocean. Fisheries Science. 69, 456-464.

Pauly, D. (1980). On the interrelationship between natural mortality, growth parameters, and mean environmental temperature in 175 fish stocks. J. Com. CIEM. 39 (2), 175-192.

Pauly, D. (1983). Some Smple Methods for the Assessment of Tropical Fish Stock. FAO Fisheries Technical Paper. (254), 52p.

Pauly, D., Ingles, J. \& Neal, R. (1984). Application to shrimp stocks of objective methods for the estimation of growth, mortality, and recruitment related parameters from length frequency data (ELEFAN I and II). In Penaeid Shrimp-Their Biology \& Management. Fishing News Book Limited. Farnham-Surrey-England. p. 220-234.

Sanchez, J.A., C.Q. Velazquez, F.G. Magana, N.B. Castillo \& R.F. Uraga. (2010). Age and growth of the silky shark Carcharhinus falciformis from the west coast of Baja California Sur, Mexico. Journal of Applied Ichthyology. 27, 20-24.

Sparre, P. \& Venema, S.C. (1999). Introduksi Pengkajian Ikan Tropis.Buku 1: Manual. Terjemahan. Pusat Penelitian dan Pengembangan Perikanan. Jakarta, 438 p.

Sparre, P. \& Venema S.C. (1992). Introduction to Tropical Fish StockAssessment. Part I. Manual FAO Fisheries Technical Paper 306/1 Rev.1. DanidaFAO.Rome. Italy. 376 hal.

Steel, R.D.G. \& Torrie, J.H. (1993). Prinsip dan Prosedur Statistika, Suatu Pendekatan Biometrik. Terjemahan B. Sumantri. Penerbit PT. Gramedia Pustaka Utama, Jakarta. 748 hal. 
Tarp, G.T. \& P.J. Kailola. 1984. Trawled Fishes of Southern Indonesia and Norhwestern Australia. ADAB-DFGGTZ. Singapore. 406p.

White, W. T., P. R. Last, J. D. Stevens, G. K. Yearsley, Fahmi \& Dharmadi. (2006). Economicaly important sharks and rays of Indonesia. National Library of Australia Cataloging-in-Publication entry. Australia. 329p.
White,W.T., Dichmont, C., Purwanto, Nurhakim, S., Dharmadi, R.J., Bucworth, R., Sadiyah,L., Faizah, R., Sulaiman,P.S. \& Sumiono,B.(2012). Tanjungluar (East Lombok) Longline Shark Fishery (p.53). Australia: Australian National Centre for Ocean Resources and Security (ANCORS). University of Wollongong. 
BAWAL. 9 (3) Desember 2017: 175-183

Lampiran 1. Distribusi frekuensi panjang total ikan hiu kejen (Carcharhinus falciformis) di perairan Selatan Nusa Tenggara pada Januari- Desember 2016.

Appendix 1. Length frequency distribution of silky shark (Carcharhinus falciformis from Southern Nusa Tenggara waters,Januari-December 2016.

\begin{tabular}{|c|c|c|c|c|c|c|c|c|c|c|c|c|}
\hline Panjang & & & & & & BUL & & & & & & \\
\hline (cmTL) & Jan & $\mathrm{Feb}$ & Mar & Apr & Mei & Jun & Jul & Agt & Sep & Okt & Nov & Des \\
\hline $70-80$ & 0 & 0 & 0 & 1 & 0 & 0 & 0 & 0 & 0 & 0 & 0 & 0 \\
\hline $80-90$ & 0 & 0 & 3 & 1 & 0 & 0 & 0 & 0 & 0 & 0 & 0 & 0 \\
\hline $90-100$ & 1 & 0 & 7 & 2 & 0 & 0 & 0 & 0 & 0 & 2 & 0 & 0 \\
\hline $100-110$ & 0 & 1 & 1 & 2 & 0 & 0 & 2 & 0 & 0 & 1 & 1 & 1 \\
\hline $110-120$ & 0 & 0 & 1 & 5 & 1 & 7 & 5 & 0 & 0 & 1 & 2 & 1 \\
\hline $120-130$ & 4 & 1 & 4 & 1 & 0 & 1 & 1 & 4 & 4 & 2 & 0 & 3 \\
\hline $130-140$ & 9 & 3 & 2 & 3 & 0 & 8 & 1 & 5 & 16 & 6 & 3 & 6 \\
\hline $140-150$ & 20 & 8 & 7 & 2 & 0 & 2 & 14 & 10 & 28 & 17 & 7 & 11 \\
\hline $150-160$ & 24 & 9 & 13 & 4 & 2 & 5 & 7 & 27 & 38 & 20 & 11 & 17 \\
\hline $160-170$ & 13 & 4 & 7 & 11 & 1 & 12 & 8 & 12 & 33 & 16 & 15 & 15 \\
\hline $170-180$ & 14 & 4 & 7 & 13 & 7 & 29 & 11 & 27 & 31 & 8 & 14 & 5 \\
\hline $180-190$ & 7 & 3 & 18 & 30 & 21 & 30 & 11 & 34 & 35 & 16 & 10 & 8 \\
\hline $190-200$ & 12 & 3 & 23 & 37 & 41 & 30 & 11 & 42 & 46 & 18 & 23 & 19 \\
\hline $200-210$ & 19 & 3 & 31 & 56 & 45 & 43 & 25 & 45 & 56 & 24 & 31 & 20 \\
\hline $210-220$ & 20 & 5 & 29 & 46 & 53 & 42 & 10 & 47 & 58 & 37 & 55 & 28 \\
\hline $220-230$ & 30 & 2 & 20 & 31 & 35 & 55 & 12 & 49 & 48 & 27 & 38 & 42 \\
\hline $230-240$ & 5 & 1 & 11 & 25 & 15 & 45 & 17 & 36 & 23 & 19 & 36 & 16 \\
\hline $240-250$ & 9 & 0 & 5 & 7 & 15 & 28 & 5 & 9 & 9 & 15 & 22 & 12 \\
\hline $250-260$ & 3 & 0 & 2 & 1 & 1 & 14 & 4 & 11 & 4 & 3 & 21 & 5 \\
\hline $260-270$ & 1 & 0 & 0 & 0 & 0 & 3 & 3 & 0 & 1 & 3 & 14 & 4 \\
\hline $270-280$ & 0 & 0 & 0 & 0 & 0 & 2 & 1 & 0 & 0 & 0 & 2 & 0 \\
\hline $280-290$ & 0 & 0 & 0 & 0 & 0 & 0 & 0 & 1 & 2 & 2 & 0 & 0 \\
\hline $290-300$ & 0 & 0 & 1 & 0 & 0 & 0 & 0 & 1 & 2 & 0 & 0 & 0 \\
\hline $300-310$ & 0 & 0 & 1 & 0 & 0 & 0 & 0 & 0 & 0 & 0 & 1 & 0 \\
\hline $310-320$ & 0 & 0 & 0 & 0 & 0 & 0 & 0 & 0 & 1 & 0 & 0 & 0 \\
\hline $320-330$ & 0 & 0 & 0 & 0 & 0 & 0 & 0 & 0 & 0 & 0 & 0 & 1 \\
\hline
\end{tabular}

